\title{
GROUNDWATER POTENTIAL ASSESSMENT USING GEOGRAPHIC INFORMATION SYSTEMS AND AHP METHOD (CASE STUDY: BAFT CITY, Kerman, IRAN)
}

\author{
M. Zeinolabedini ${ }^{*}$, A. Esmaeily ${ }^{\mathrm{b}}$ \\ Dept. of Water Resources Engineering, Graduate University of Advanced Technology, Kerman, Mahan, 7631133131, \\ Iran - ze.maryam@yahoo.com \\ Dept. of Remote Sensing Engineering, Graduate University of Advanced Technology, Kerman, Mahan, 7631133131, \\ Iran - aliesmaeily@kgut.ac.ir

\section{Commission VI, WG VI/4}

KEY WORDS: Underground Water, AHP, GIS, Remote Sensing

\section{ABSTRACT:}

The purpose of the present study is to use Geographical Information Systems (GISs) for determining the best areas having ground water potential in Baft city. To achieve this objective, parameters such as precipitation, slope, fault, vegetation, land cover and lithology were used. Regarding different weight of these parameters effect, Analytic Hierarchy Process (AHP) was used. After developing informational layers in GIS and weighing each of them, a model was developed. The final map of ground waters potential was calculated through the above-mentioned model. Through applying our developed model four areas having high, average, low potential and without required potential distinguished. Results of this research indicated that $0.74,41.23$ and 45.63 percent of the area had high, average and low potential, respectively. Moreover, $12.38 \%$ of this area had no potential. Obtained results can be useful in management plans of ground water resources and preventing excessive exploitation.

\section{INTRODUCTION}

Ground water is a main source for industries, communities and agricultural consumptions in the world and due to its freshness, chemical compounds, constant temperature, lower pollution coefficient and higher reliability level, considered as a basic source of supplying reliable fresh water in urban and rural areas. Nowadays, about $34 \%$ of the world's water resources belong to ground water and is an important source of drinkable water. Iran is an arid and semi arid country with very little rainfall; so that its average annual rainfall is lower than one-third of the world's average annual rainfall (Nampak et al., 2014; Rahimi \& Moosavi, 2013; Magesh et al., 2012; Seif \& Kargar, 2011). Therefore, recognizing these resources and optimal usage of them, means stable and permanent usage of this natural wealth A common method for preparing ground water potential maps is based on land surveying. Recently, with the help of GIS and RS technologies, potential detection of ground water resources can be done easier, more accurate and in short-time.

GIS is a powerful tool to address a large number of spatial data and can be used in detection process of potential ground water areas. Recently, many studies conducted through indices of ground water potential models. Some of them are as follows: frequency ratio, weights of evidence and AHP. In the present study, analytic hierarchy process and GIS technique used to determine the best water resources for optimal usage of ground water resources in Baft city. AHP can be done in different ways, one of these methods is to use expert choice software which its implementation and calculation stages done automatically (Nampak et al., 2014; Magesh et al., 2012; Al-Harbi, 2001).

Moreover, different studies conducted through GIS technique. Using GIS, Abdalla, 2012, Venkateswaran et al., 2015, Dar et al., 2010, Nampak et al., 2014 and Elbeih 2015, studied underground resources of eastern and central desert of Egypt, underground resources potential in hard stones of Gadilam river basin, ground water conditions of Mamundiyar basin in Tamilandu, spatial efficiency prediction of underground resources of Langat basin in Malaysia and underground resources in Europe, respectively. Rahimi et al., 2013, Seif et al. 2011 and Yamani et al., 2014 researches were in line with the above-mentioned studies (Abdalla, 2012; Venkateswaran \& Ayyandurai, 2015; Dar et al., 2010; Nampak et al., 2014; Elbeih, 2015; Rahimi \& Moosavi, 2013; Seif \& Kargar, 2011; Yamani \& Alizadeh, 2014). This study tries to determine the 
best water resources of the area (for optimal usage and preventing excessive exploitation) through analyzing effective parameters on ground water aquifers feeding, exfoliation, raster, weighting to components by means of analytic hierarchy process and combining layers in ArcGIS environment.

\section{STUDY AREA}

Baft is one of the oldest and most important cities of Kerman. The city is located in the southwest of the province and its center is Baft, it is $156 \mathrm{~km}$ away from Kerman with an area of 13162 square kilometers and located at an altitude of 2250 meters above sea level and 29 degrees 17 minutes of north latitude and 56 degrees and 36 minutes of east longitude (Figure 1). According to the last official statistics, its population is about 131567 individuals and is one of the rainiest cities of Kerman. Baft is known as the heaven of Kerman province, but in recent days, excessive usage of ground water resources resulted in water rationing. The main reason of water shortage in Baft city is plantation in surrounding plains which leads to withdrawal of considerable volume of ground water.

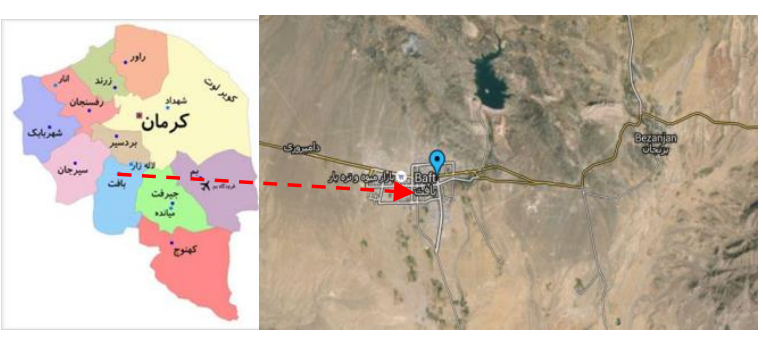

Figure 1. Geographical location of the study area

\section{DATA AND METHODS}

At first, with the help of Google Earth satellite images, the study area studied and determined. Then, in order to zone the area in terms of ground water resources potential, the following steps performed:

\subsection{Parameters and layers generation}

In the present study, precipitation, slope, fault, lithology, vegetation and land cover layers used to detect water resources having different potentials. Vegetation layer is a product of NDVI of Modis sensor with spatial accuracy of $250 \mathrm{~m}$, and Dem of Aster sensor with spatial accuracy of $30 \mathrm{~m}$ and altitudinal accuracy of $20 \mathrm{~m}$. Information of 23 weather station's annual precipitation (1962-2006) presented here. Layers obtained from satellite images.

\subsection{AHP processing}

Analytic hierarchy process (AHP) is one of the most effective multi-criteria decision making (MCDM) techniques which helps a decision maker facing complex problems and conflict and internal multiple criteria. This method first presented by Thomas L. Saaty (1980) and like other MCDMs such as Mabeth, Electre, Smart, Promeyhee, VTA and etc. has 4 steps including 1) problem modelling and making hierarchical structure, 2) evaluating weights, 3) combining weights and 4) analyzing sensitivity. Implementing AHP method with the help of expert choice software is so easy, since accessing to it is easy and its implementation and calculation steps done automatically. In addition to the possibility of designing hierarchical diagram, decision making, designing questions, determining priorities and calculating the final weight, the above-mentioned software can analyze the sensitivity of decision making about the changes of problem parameters. In most cases, appropriate diagrams and graphs used for presenting results and performances and a user can communicate easily. In this research, after obtaining available layers through remote sensing data and other available resources, all layers analyzed in Arc Gis environment and converted to raster data. Using expert choice software, an inter-criterion and intra-criterion weight determined for layers and their classes, respectively. Finally, with the help of ArcGIS software and Raster Calculator toolbox, layers overlapped and potential map and ground water obtained (Rahimi \& Moosavi, 2013; Ishizaka \& Labib, 2009; Al-Harbi, 2001; Zhu \& Xu, 2014).

\section{RESULTS}

\subsection{Weighting and layers}

Tables 1 to 6 show the results of weighting each parameter and according to weighting method, inter and intra-criterion weights calculated.

\begin{tabular}{|c|c|c|c|c|}
\hline $\begin{array}{l}\text { Inter- } \\
\text { critrion } \\
\text { weight }\end{array}$ & $\begin{array}{l}\text { Intra- } \\
\text { critrion } \\
\text { weight }\end{array}$ & $\begin{array}{l}\text { Precipitation } \\
\text { level }\end{array}$ & $\begin{array}{l}\text { Weighting } \\
\text { method }\end{array}$ & 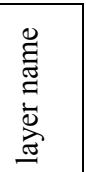 \\
\hline \multirow{4}{*}{0.38} & 0.0 & Very low & \multirow{4}{*}{$\begin{array}{c}\text { More } \\
\text { Precipitation, } \\
\text { higher } \\
\text { weight }\end{array}$} & \multirow{4}{*}{ 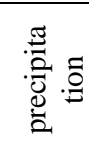 } \\
\hline & 0.1 & Low & & \\
\hline & 0.33 & average & & \\
\hline & 0.57 & high & & \\
\hline
\end{tabular}

Table 1. Weighting precipitation 
The International Archives of the Photogrammetry, Remote Sensing and Spatial Information Sciences, Volume XL-1/W5, 2015 International Conference on Sensors \& Models in Remote Sensing \& Photogrammetry, 23-25 Nov 2015, Kish Island, Iran

\begin{tabular}{|c|c|c|c|c|}
\hline $\begin{array}{c}\text { Inter- } \\
\text { critrion } \\
\text { weight }\end{array}$ & $\begin{array}{c}\text { Intra- } \\
\text { critrion } \\
\text { weight }\end{array}$ & $\begin{array}{c}\text { Vegetation } \\
\text { level }\end{array}$ & Weighting method & 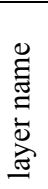 \\
\hline \multirow{4}{*}{0.20} & 0.0 & $\begin{array}{c}\text { No } \\
\text { vegetation }\end{array}$ & \multirow{4}{*}{$\begin{array}{l}\text { According to the } \\
\text { vegetation, the area } \\
\text { divided into } 4 \\
\text { subareas, the more } \\
\text { weight, the better } \\
\text { vegetation }\end{array}$} & \multirow{4}{*}{ 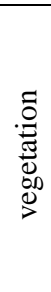 } \\
\hline & 0.1 & $\begin{array}{c}\text { Low } \\
\text { vegetation }\end{array}$ & & \\
\hline & 0.33 & $\begin{array}{c}\text { Average } \\
\text { vegetation }\end{array}$ & & \\
\hline & 0.57 & $\begin{array}{c}\text { High } \\
\text { vegetation }\end{array}$ & & \\
\hline
\end{tabular}

Table 2. Weighting vegetation

\begin{tabular}{|c|c|c|c|c|c|}
\hline 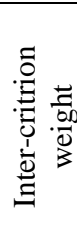 & 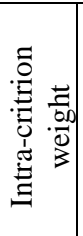 & Period & 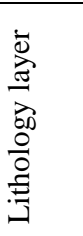 & $\begin{array}{l}\text { Weighting } \\
\text { method }\end{array}$ & 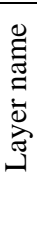 \\
\hline \multirow{5}{*}{0.10} & $\underset{0}{0}$ & $\begin{array}{c}2.5 \\
\text { billion to } \\
542 \\
\text { million } \\
\text { years ago }\end{array}$ & 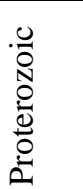 & \multirow{5}{*}{$\begin{array}{l}\text { According to } \\
\text { age, the area } \\
\text { divided into } 5 \\
\text { subareas. The } \\
\text { more age, the } \\
\text { more density } \\
\text { and the lower } \\
\text { coefficient }\end{array}$} & \multirow{5}{*}{ 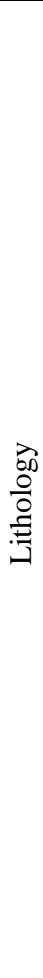 } \\
\hline & $\stackrel{0}{\circ}$ & $\begin{array}{c}554 \\
\text { million } \\
\text { to } 248 \\
\text { million } \\
\text { years ago }\end{array}$ & 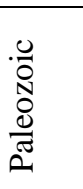 & & \\
\hline & $\frac{9}{0}$ & $\begin{array}{c}240 \\
\text { million } \\
\text { years ago }\end{array}$ & 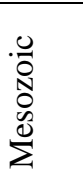 & & \\
\hline & $\bar{n}$ & $\begin{array}{c}150 \\
\text { million } \\
\text { years ago }\end{array}$ & 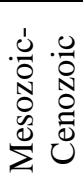 & & \\
\hline & $\stackrel{\text { I }}{0}$ & $\begin{array}{c}65 \\
\text { million } \\
\text { years ago }\end{array}$ & 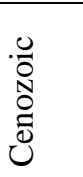 & & \\
\hline
\end{tabular}

Table 3. Weighting lithology

\begin{tabular}{|c|c|c|c|c|}
\hline $\begin{array}{c}\text { Inter- } \\
\text { critrion } \\
\text { weight }\end{array}$ & $\begin{array}{c}\text { Intra- } \\
\text { critrion } \\
\text { weight }\end{array}$ & $\begin{array}{c}\text { Land cover } \\
\text { layer }\end{array}$ & $\begin{array}{l}\text { weighting } \\
\text { method }\end{array}$ & $\begin{array}{l}\stackrel{\Xi}{\Xi} \\
\stackrel{\Xi}{\Xi} \\
\stackrel{\Xi}{\Xi}\end{array}$ \\
\hline \multirow{9}{*}{0.04} & 0.02 & Rock & \multirow{9}{*}{$\begin{array}{l}\text { Land divided } \\
\text { into } 9 \text { areas. } \\
\text { The more } \\
\text { fertility and } \\
\text { penetration, } \\
\text { the more } \\
\text { coefficients }\end{array}$} & \multirow{9}{*}{ 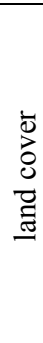 } \\
\hline & 0.03 & Poor-range & & \\
\hline & 0.04 & Mod-range & & \\
\hline & 0.05 & way & & \\
\hline & 0.07 & Urban & & \\
\hline & 0.11 & Woodland & & \\
\hline & 0.15 & Garden & & \\
\hline & 0.22 & Agri & & \\
\hline & 0.31 & forest & & \\
\hline
\end{tabular}

Table 4. Weighting land cover

\begin{tabular}{|c|c|c|c|c|}
\hline $\begin{array}{c}\text { Inter- } \\
\text { critrion } \\
\text { weight }\end{array}$ & $\begin{array}{c}\text { Intra-critrion } \\
\text { weight }\end{array}$ & $\begin{array}{c}\text { Slope } \\
\text { (degree) }\end{array}$ & $\begin{array}{c}\text { weighting } \\
\text { method }\end{array}$ & 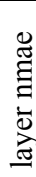 \\
\hline \multirow{5}{*}{0.26} & 0.51 & $0-10$ & \multirow{5}{*}{$\begin{array}{c}\text { The area divided } \\
\text { in to } 5 \text { subareas. } \\
\text { The more } \\
\text { slope,the lower } \\
\text { coefficient. }\end{array}$} & \multirow{5}{*}{$\frac{0}{0}$} \\
\hline & 0.27 & $10-25$ & & \\
\hline & 0.13 & $25-45$ & & \\
\hline & 0.06 & $45-65$ & & \\
\hline & 0.03 & $65-90$ & & \\
\hline
\end{tabular}

Table 5. Weighting slope

\begin{tabular}{|c|c|c|c|c|}
\hline 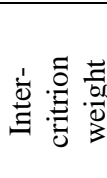 & $\begin{array}{r}\text { Intra- } \\
\text { critrion } \\
\text { weight }\end{array}$ & Fault density & $\begin{array}{l}\text { weighting } \\
\text { method }\end{array}$ & 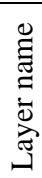 \\
\hline \multirow{9}{*}{0.02} & 0.02 & $0.0-0.009542$ & \multirow{9}{*}{$\begin{array}{c}\text { according } \\
\text { to fault } \\
\text { density, the } \\
\text { area divided } \\
\text { into } 9 \\
\text { classes. The } \\
\text { more fault } \\
\text { density, the } \\
\text { more } \\
\text { weight }\end{array}$} & \multirow{9}{*}{ 节 } \\
\hline & 0.03 & $0.009542-0.27874$ & & \\
\hline & 0.04 & $0.27874-0.0502366$ & & \\
\hline & 0.05 & $0.0522366-0.076922$ & & \\
\hline & 0.07 & $0.076922-0.108541$ & & \\
\hline & 0.11 & $0.108541-0.145761$ & & \\
\hline & 0.15 & $0.145761-0.190367$ & & \\
\hline & 0.22 & $0.190367-0.255811$ & & \\
\hline & 0.31 & $0.255611-0.354819$ & & \\
\hline
\end{tabular}

Table 6. Weighting faults density

\subsection{Classified map generation}

After weighting and regarding their spatial position, each parameter classified and obtained results presented in figures 2 to 7 . 


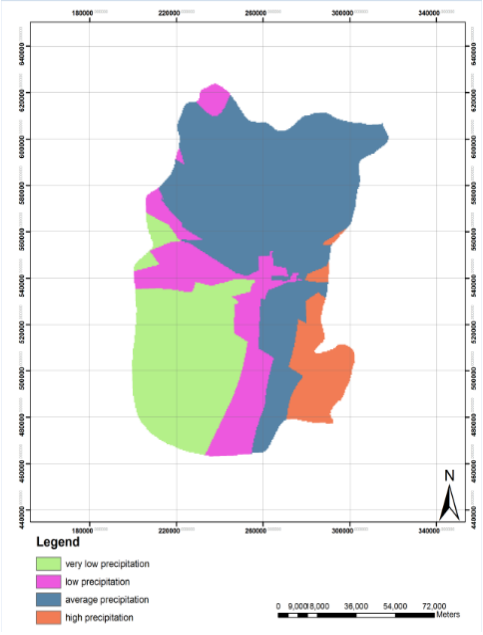

Figure 2. precipitation classification map

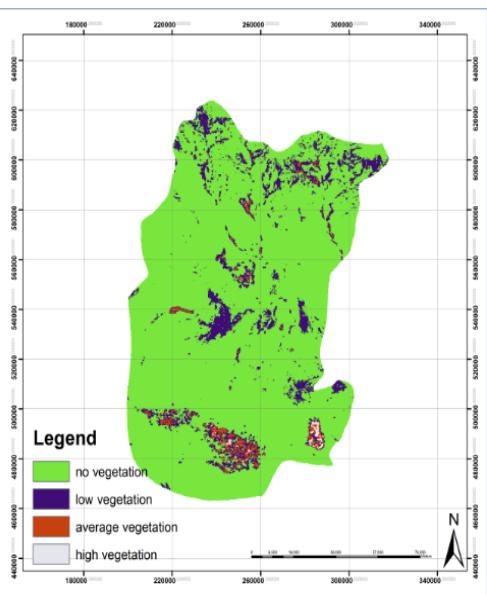

Figure 3. Vegetation classification map

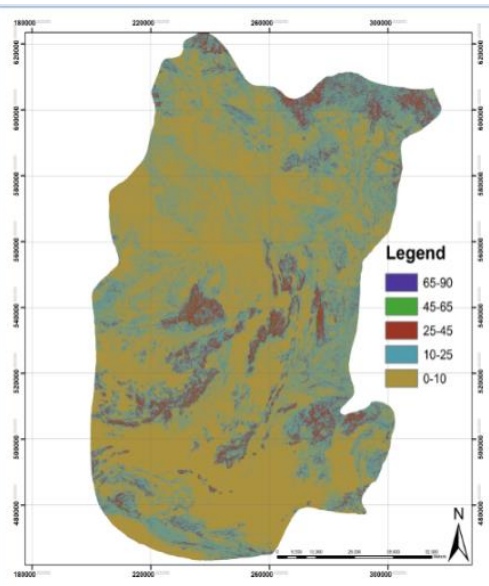

Figure 4. Slope classification map

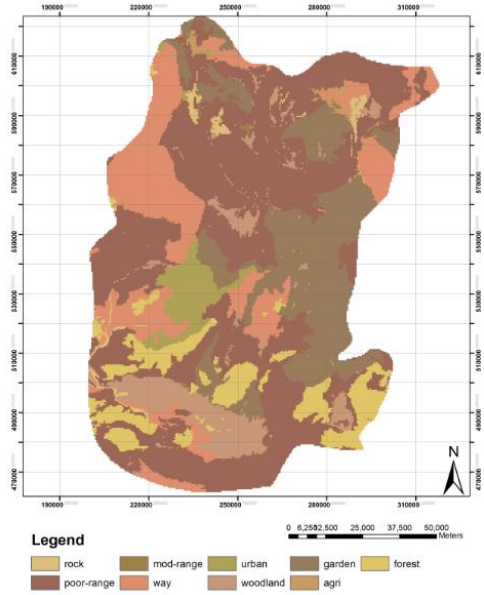

Figure 5. land cover classification map

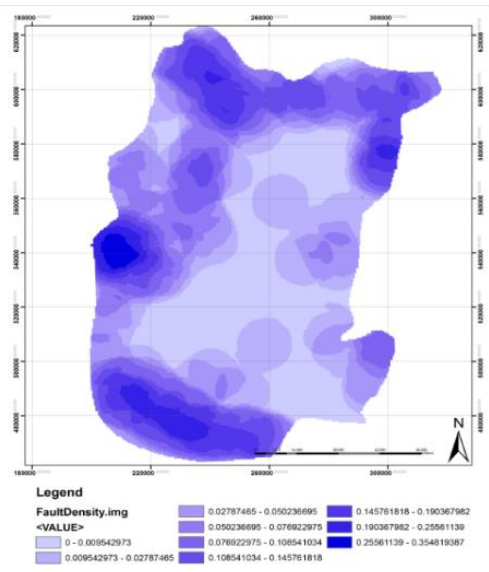

Figure 6. Fault classification map

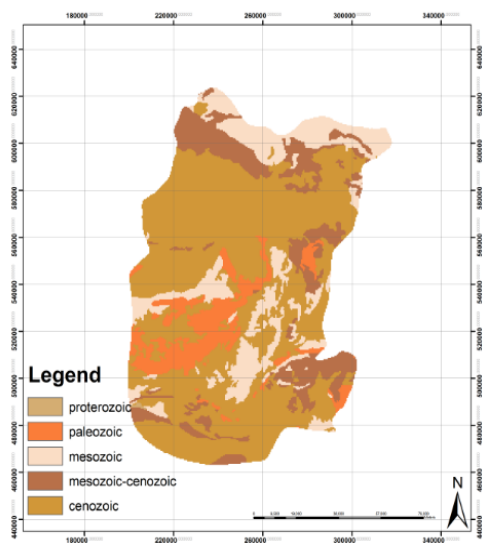

Figure 7. Lithology classification map

\section{FINAL MAP}

In order to determine areas having ground water resources, a weighted overlap mathematical model used. Mathematical overlap result is a suitability map which regulated in terms of the degree of suitability and included different spectra of colors. 
Each layer has an inter-criterion weight. In order to prepare ground waters potential map, we can put all weights in the following formula:

\section{$\mathrm{GP}=0.04 * \mathrm{RC}+0.26 * \mathrm{RS}+0.02 * \mathrm{RF}+0.10 * \mathrm{RL}+0.38 * \mathrm{RP}+0.2 * \mathrm{RV}$}

Where $\mathrm{RP}=$ raster-precipitation map

$$
\begin{aligned}
& \mathrm{RL}=\text { raster-lithology map } \\
& \mathrm{RF}=\text { raster-fault map } \\
& \mathrm{RS}=\text { raster-slope map } \\
& \mathrm{RC}=\text { raster-land cover map }
\end{aligned}
$$

And

$\mathrm{RV}=$ raster-vegetation map

After overlapping layers, the final potential map divided into 4 areas (figure 8 ) and then, in order to show water potential map of the area, histogram related to it presented. It shows that only $0.74 \%$ of the study area has high potential of water resources (figure 9).

The results show that high-potential area is located in the southeast region and around forest areas (with average vegetation and high precipitation). Moreover, this zone is related to Cenozoic period (minimum age) and its slope is very low (0-10 degrees). The zone without required potential is located in central, west and southwest areas and its precipitation and slope are very low and high, respectively and our considered zone has no vegetation. Fault density in both zones is low, but since precipitation and slope layers have most coefficients, the area with high precipitation and low slope and the area with very low precipitation and high slope located in the zone with high potential and the zone without required potential, respectively.

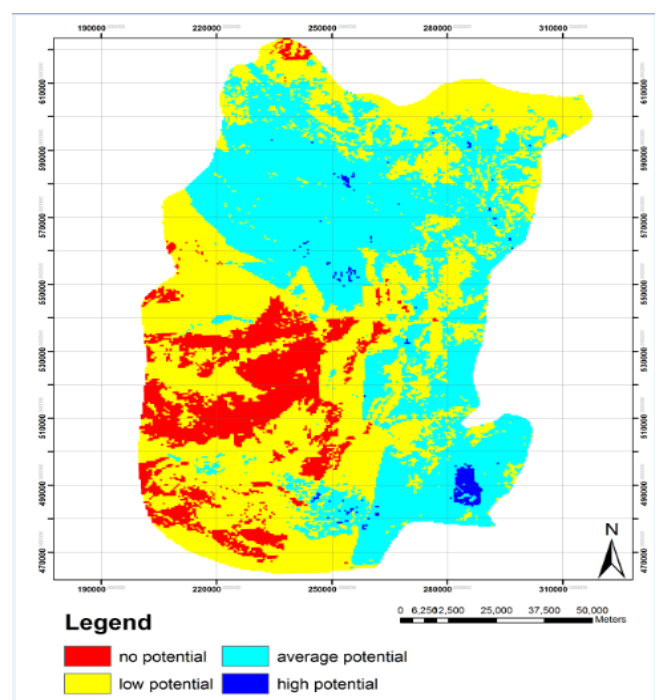

Figure 8 . The final map of ground water potential

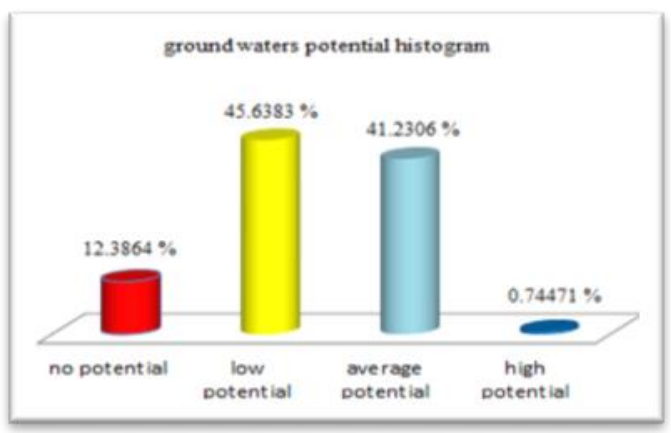

Figure 9. Ground waters potential histogram

\section{CONCLUSION}

The present study shows that GIS is an appropriate tool for evaluating ground water potential. Based on GIS, appropriate locations for drilling wells and ground water withdrawal can be determined. In addition, AHP used by programmers for solving complex problems of management and expert choice software makes its implementation easier (Ganapuram et al.,2009; Abdalla, 2012; Venkateswaran \& Ayyandurai, 2015).

In this study, combining spatial data in GIS and expert choice software was used in order to determine areas having high potential for ground water resources. 6 different layers including precipitation, vegetation, land cover, lithology, slope and fault used. Each of them and their classes had inter and intra criterion weights, respectively. Finally, through putting 6 layers on each other, potential map prepared. Final map divided into four areas which showed $0.74,41.23$ and 45.63 percent of the area had high, average and low potential, respectively. Moreover, $12.38 \%$ of this area had no potential (figures 8 and 9). 


\section{References}

Al-Harbi, K.M.A.S., 2001. Application of the AHP in project management, International journal of project management, 19(1), pp. 19-27.

Damavandi, A.; Rezaei F.; Panahi, M., 2011. Ground water potential zoning using RS and GIS in Sele Ben Watershed, Second Conference in Geoscience. Tehran, Iran (In Persian)

Dar, I.A.; Sankar, K.; Dar, M.A. 2010. Remote sensing technology and geographic information system modeling: An integrated approach towards the mapping of groundwater potential zones in Hardrock terrain, Mamundiyar basin, Journal of Hydrology, 394(3-4), pp. 285-295.

Elbeih, S.F. 2015. An overview of integrated remote sensing and GIS for groundwater mapping in Egypt, Ain Shams Engineering Journal, 6(1), pp. 1-15.

Ganapuram, S.; Kumar, G.T.V.; Krishna, I.V.M.; Kahya, E, 2009. Mapping of groundwater potential zones in the musi basin using remote sensing data and GIS, Advanced in engineering software, 40(7), pp. 506-518.

Ishizaka, A., Labib A. 2009. Analytic Hierarchy Process and Expert Choice: Benefits and limitations, OR Insight, V. 22, pp. 201-220.

Magesh, N.S.; Chandrasekar, N.; Soundranayaga J.P. 2012. Delineation of groundwater potential zones in Thenim district, Tamil Nadu, using remote sensing, GIS and MIF Techniques, Geoscience Frontiers, 3(2), pp. 189-196.

Nampak, H.; Pradhan, B.; Manap, M.A. 2014. Application of GIS based data driven evidential belief function model to predict groundwater potential zonation, Journal of Hydrology, V. 513, pp. 283-300.

Oikonomidis, D.; Dimogianni, S.; Kazakis, N.; Voudoiri, K. 2015. A GIS/remote sensing-based methodology for groundwater potentiality assessment in Timavos area Greece, Journal of Hydrology, V. 525, pp. 197-208.

Rahimi, D.; Moosavi, H., 2013. Potentiality of ground water resources by using AHP model and GIS technique in ShahroodBastam watershed, Journal of Geography and Management, 17(44), pp. 139-159. (In Persian)

Seif, A.; Kargar, A., 2011. Ground water potential zoning using AHP and GIS in Sirjan Watershed, Journal of Natural Gegraphy, 4(12), pp. 75-90. (In Persian)

Sternberg, T.; Paillou, Ph. 2015. Mapping potential shallow groundwater in the desert using remote sensing: Lake Ulaan Nurr, Journal of Enviroments,

Venkateswaran, S.; Ayyandurai, R., 2015. Groundwater Potential Zoning in Upper Gadilam River Basin Tamil Nadu, Aquatic Procedia, V. 4, pp.1275-1282.

Zhu, B.; Xu, Z. 2014. Analytic hierarchy process-hesitant group decision making, European Journal of Operational Research, 239(3), pp. 794-801.
Yamani, M.; Alizadeh, Sh. 2014. Ground water potential zoning using AHP in Abadeh-Fars, journal of Geomorphology, 1(1),pp.131-144.(In Persian)

Abdalla, F.2012. Mapping of groundwater prospective zones using remote sensing and GIS techniques: A case study from the Central Eastern Desert, Egypt, journal of African Earth Sciences, 70(1-2), pp.8-17 